\title{
Structural Characterization of Degrader-Induced Ternary Complexes using HDX-MS and Computational Modeling: Implications for Structure-Based Design
}

Scott J. Eron ${ }^{1}$, Hongwei Huang ${ }^{1}$, Roman V. Agafonov ${ }^{1}$, Mark E. Fitzgerald ${ }^{1}$, Joe Patel ${ }^{1}$, Ryan E. Michael ${ }^{1}$, Tobie D. Lee ${ }^{1}$, Ashley A. Hart ${ }^{1}$, Jodi Shaulsky ${ }^{2}$, Christopher G. Nasveschuk ${ }^{1}$, Andrew J. Phillips ${ }^{1}$, Stewart L. Fisher ${ }^{1}$, Andrew Good ${ }^{* 1}$

\author{
Affiliations \\ ${ }^{1}$ C4 Therapeutics, Inc., 490 Arsenal Way Suite 200, Watertown MA, 02472, United States \\ 2 Dassault Systèmes BIOVIA, 5005 Wateridge Vista Dr, San Diego, CA 92121, United States \\ ${ }^{*}$ Corresponding author: Dr. Andrew Good \\ E-mail: agood@c4therapeutics.com
}

\section{Supporting Information}

Table S1. Summary of binding data, ternary complex formation, and degradation parameters

Table S2. Crystallography data collection, processing, and refinement statistics for BRD4(BD1) co-crystallized with CFT-0308

Figure S1. Sequence coverage map for the peptic peptides of BRD4 (BD1) and CRBN from HDX-MS

Figure S2. Crystal structure for BRD4 (BD1) ligand CFT-0308

Figure S3. CRBN-DDB1 construct design and HDX considerations

Figure S4. Formation of the ternary complex with CFT-1297 did not result in additional shielding on DDB1 or the portion of CRBN that inserts into the DDB1 domain

Figure S5. CRBN-DDB1 $\triangle \mathrm{BPB}$ alone reveals conformational dynamics of protein

Figure S6. CRBN peptides from the ternary complex with dBET6 show no significant difference in deuterium uptake compared to the binary compound-only experiment

Figure S7. Computational workflow and HDX scoring

Figure S8. Symmetry mates and crystal contacts for the ternary complex BD1-dBET6-CRBNDDB1 $\triangle \mathrm{BPB}$

\section{Additional Methods}

Extended chemical syntheses: Synthesis of CFT-1297, CFT-0308, and dBET6

\section{References}




\begin{tabular}{|c|c|c|}
\hline Binding & $\begin{array}{c}\text { BD1 } \\
K_{d}(n M)\end{array}$ & $\begin{array}{c}\text { CRBN } \\
K_{d}(n M)\end{array}$ \\
\hline dBET6 & $46 \pm 34$ & $264 \pm 33$ \\
\hline CFT-0308 & $84 \pm 26$ & $>3100$ \\
\hline CFT-1297 & $58 \pm 24$ & $2100 \pm 280$ \\
\hline
\end{tabular}

\begin{tabular}{|c|c|c|c|}
\hline Ternary Complex & $\mathrm{K}_{\mathrm{ff}}(\mathrm{nM})$ & $\mathrm{K}_{\mathrm{ti}}(\mathrm{nM})$ & Max Fraction (\%) \\
\hline dBET6 & $33 \pm 1$ & $120 \pm 4$ & $4.1 \pm 0.2$ \\
\hline CFT-0308 & $\mathrm{ND}$ & $\mathrm{ND}$ & 0 \\
\hline CFT-1297 & $4 \pm 4$ & $1820 \pm 310$ & $6.7 \pm 0.5$ \\
\hline
\end{tabular}

\begin{tabular}{|c|c|c|}
\hline Degradation & $\begin{array}{c}\mathrm{DC}_{50} \\
(\mathrm{nM})\end{array}$ & $\mathrm{E}_{\max }(\%)$ \\
\hline $\mathrm{dBET6}$ & $6 \pm 1$ & $3 \pm 1$ \\
\hline CFT-0308 & $>10000$ & $\mathrm{ND}$ \\
\hline CFT-1297 & $5 \pm 1$ & $5 \pm 2$ \\
\hline
\end{tabular}

Table S1. Summary of binding data, ternary complex formation, and degradation parameters. Data are shown as the mean \pm SD for three separate experiments on three separate days. 


\begin{tabular}{|c|c|}
\hline $\begin{array}{l}\text { Data Collection } \\
\text { Space Group }\end{array}$ & P1 \\
\hline \multicolumn{2}{|l|}{ Cell Dimensions } \\
\hline$a, b, c(\AA)$ & $30.4,39.7,57.8$ \\
\hline$\alpha, \beta, y\left({ }^{\circ}\right)$ & $82.2,75.3,89.9$ \\
\hline Wavelength & 0.966 \\
\hline Resolution $(\AA)$ & $\begin{array}{l}55.4-1.55 \\
(1.58-1.55)\end{array}$ \\
\hline No. unique reflections & 33390 \\
\hline $\mathrm{R}_{\text {merge }}$ & $0.089(0.53)$ \\
\hline $\mathrm{R}_{\text {meas }}$ & $0.126(0.751)$ \\
\hline Mean I/ $\sigma$ & $3.2(1.4)$ \\
\hline Completeness (\%) & $88.7(90.2)$ \\
\hline Multiplicity & 1.5 \\
\hline $\begin{array}{l}\mathrm{CC}_{1 / 2} \\
\text { Refinement }\end{array}$ & $0.987(0.601)$ \\
\hline Resolution $(\AA)$ & 1.55 \\
\hline No. unique reflections & 31495 \\
\hline Average B Value $\left(\AA^{2}\right)$ & 12.4 \\
\hline $\mathrm{R}_{\text {work }} / \mathrm{R}_{\text {free }}$ & $0.21 / 0.24$ \\
\hline \multicolumn{2}{|l|}{ RMS deviations } \\
\hline Bond lengths $(\AA)$ & 0.009 \\
\hline Bond angles $\left({ }^{\circ}\right)$ & 1.59 \\
\hline \multicolumn{2}{|l|}{ Ramachandran plot (\%) } \\
\hline Favored & 98.3 \\
\hline Allowed & 1.7 \\
\hline Outliers & 0 \\
\hline
\end{tabular}

Values in parentheses are for the highest resolution bin RMSD, root-mean-square-deviation

Table S2. Crystallography data collection, processing, and refinement statistics for BRD4 (BD1) co-crystallized with CFT-0308 
A. BRD4 (BD1)

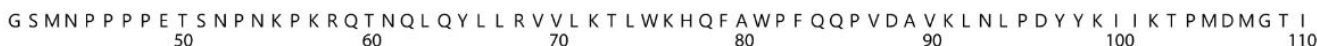
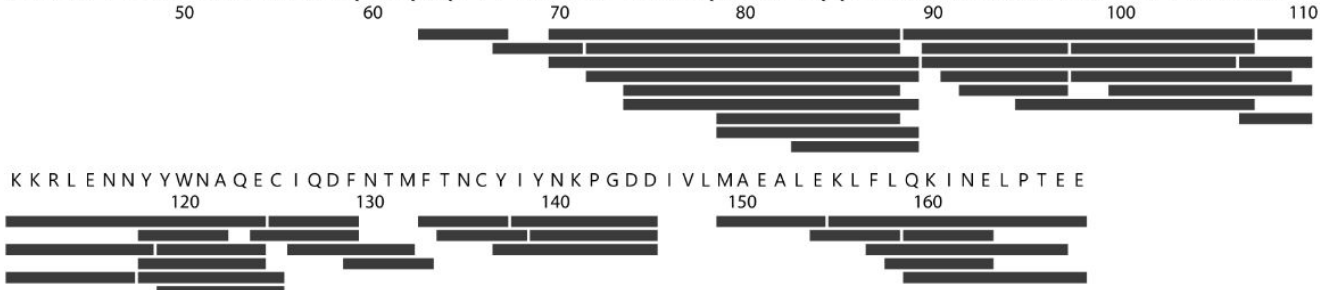

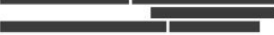

Total 45 peptides; $80.5 \%$ coverage; 4.3 redundancy

\section{B. CRBN}
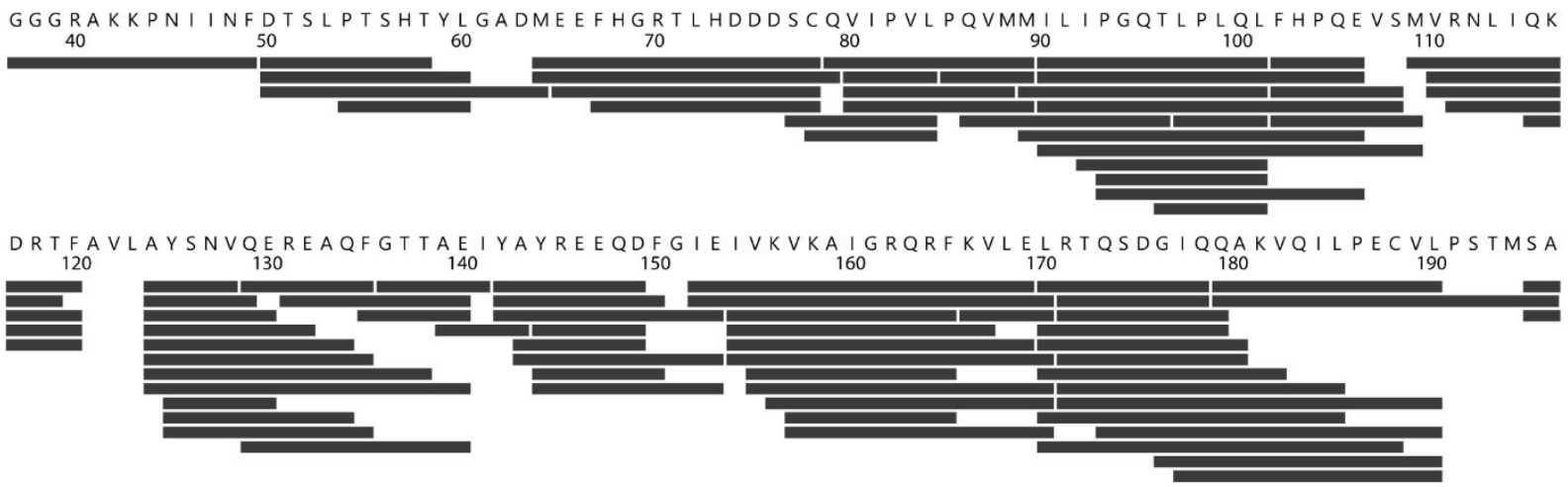

VQLESLNKCQIFPSKPVSREDQCSYKWWQKYQKRKFHCANLTSWPRWLYSLYDAETLMDRIKKQLREWDENLKDDSLPSN

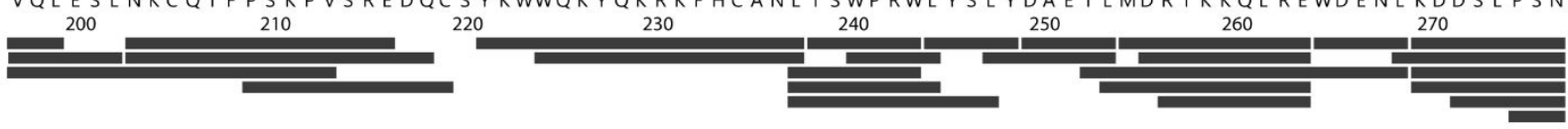

P I DFSYRVAACLPIDDVLRIQLLKIGSA I QRLRCELDIMNKCTSLCCKQCQETE ITTKNE IFSLSLCGPMAAYVNPHGYV

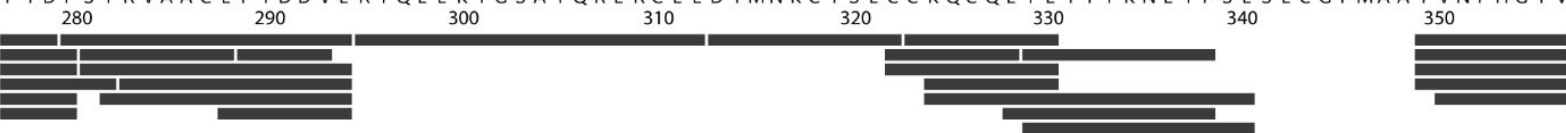

HETLTVYKACNLNLIGRPSTEHSWFPGYAWT VAQCK I CASH I GWKF TATKKDMSPQKFWGLTRSALLPTIPDTEDE ISPD

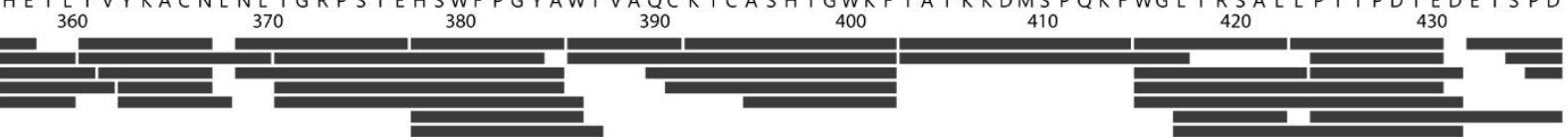

$\begin{array}{r}K V \quad I \quad L C \\ \quad 440 \\ \hline\end{array}$

Total 173 peptides; $96.8 \%$ coverage; 4.8 redundancy

Figure S1. Sequence coverage map for the peptic peptides of (A) BRD4 (BD1) and (B) CRBN that were identified in HDX-MS. 

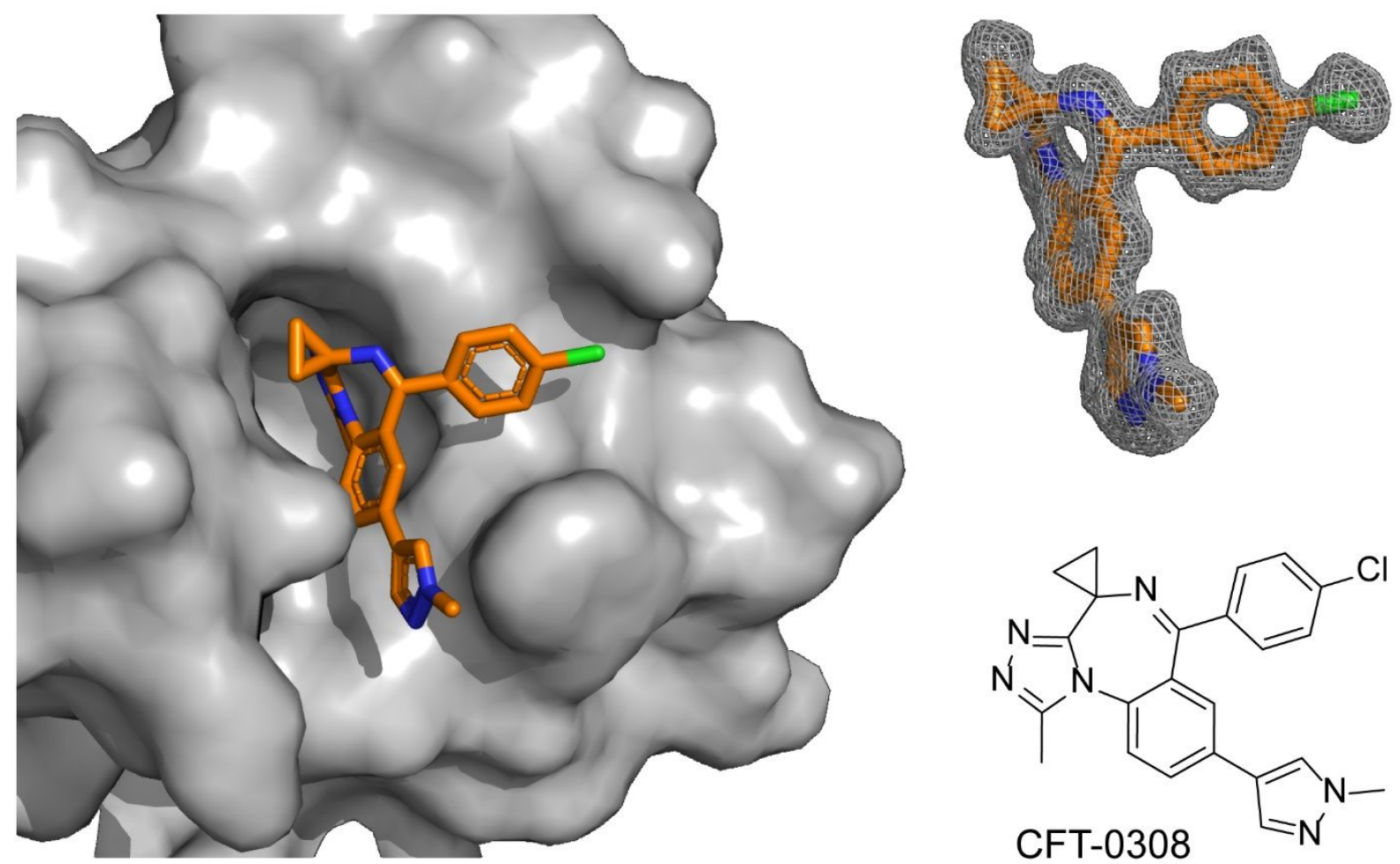

Figure S2. Crystal structure for BRD4 (BD1) ligand CFT-0308

Surface representation of BRD4 (BD1) binding pocket (left) and density for the ligand shown with $2 \mathrm{Fo}-\mathrm{Fc}$ map contoured at $1 \sigma$ (right). 
A.
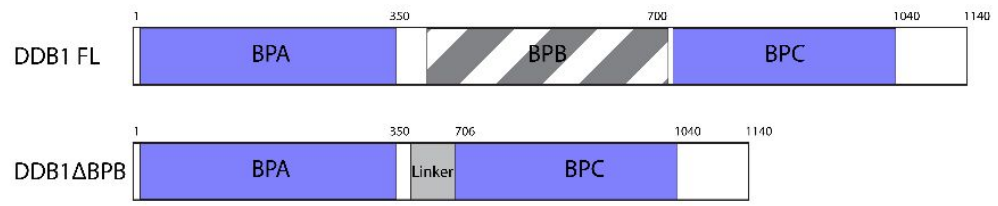

CRBN

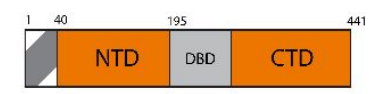

B.

CRBN-DDB1 FL CRBN-DDB1 $\triangle \mathrm{BPB}$
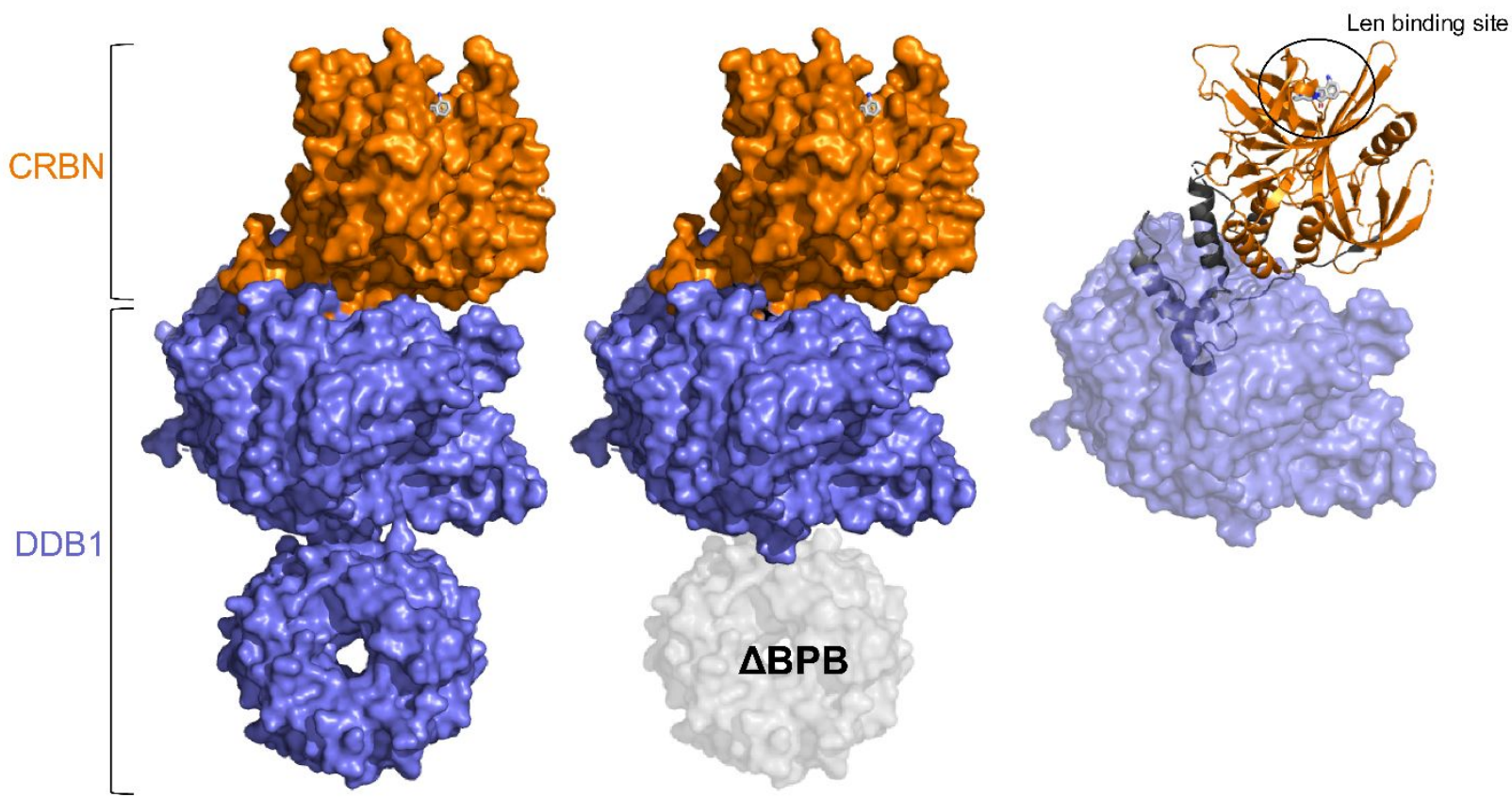

Figure S3. CRBN-DDB1 construct design and HDX considerations

(A) Cartoon representation of the protein constructs. Dashed gray regions were omitted. BPA ( $\beta$-propeller A), BPB ( $\beta$-propeller B), BPC ( $\beta$-propeller $C)$, NTD ( $N$-terminal domain), DBD (DDB1 binding domain), and CTD (C-terminal domain).

(B) Surface representation of full length CRBN-DDB1 (left; PDB: 4TZ4) with CRBN in orange, DDB1 in blue, and lenalidomide in gray sticks. Deletion of the $\beta$-propeller 'B' (BPB, middle) does not affect the substrate binding pocket. (Right) CRBN cartoon (orange) highlighting regions in the HDX analysis. Black regions make up the DDB1 binding domain (DBD). 


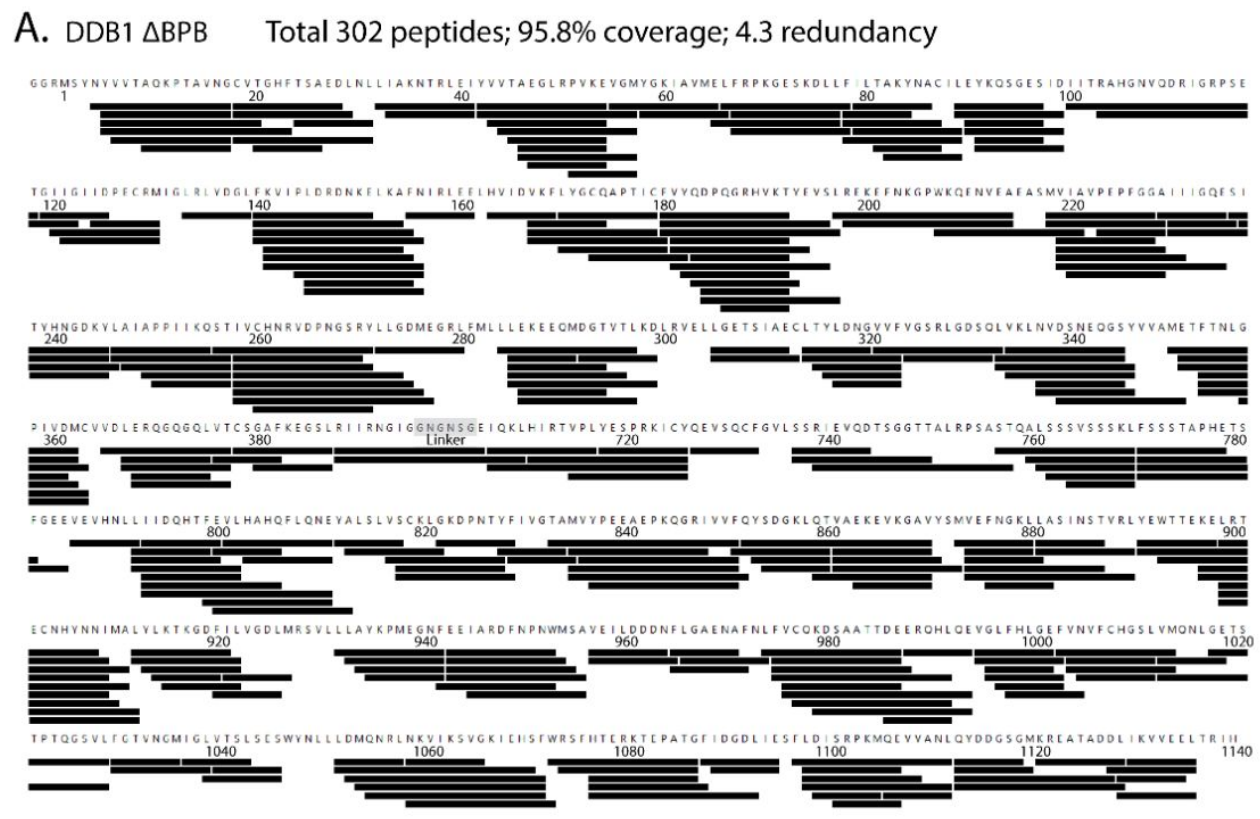

C. CRBN (DDB1 Binding Peptides)

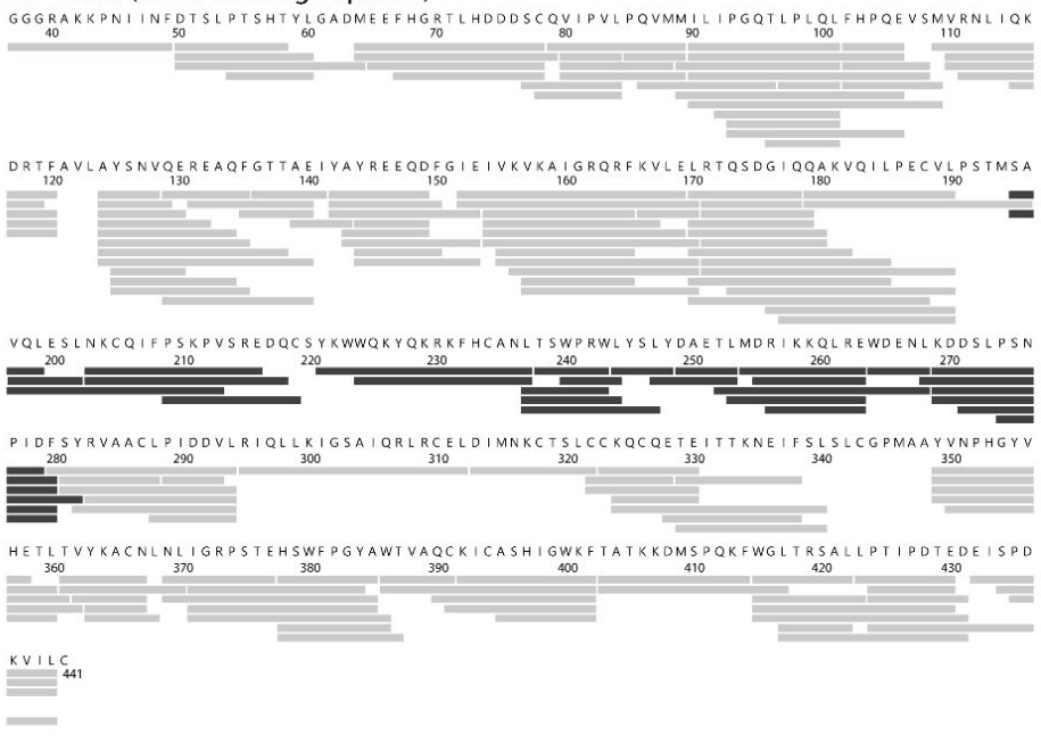

D.

B.

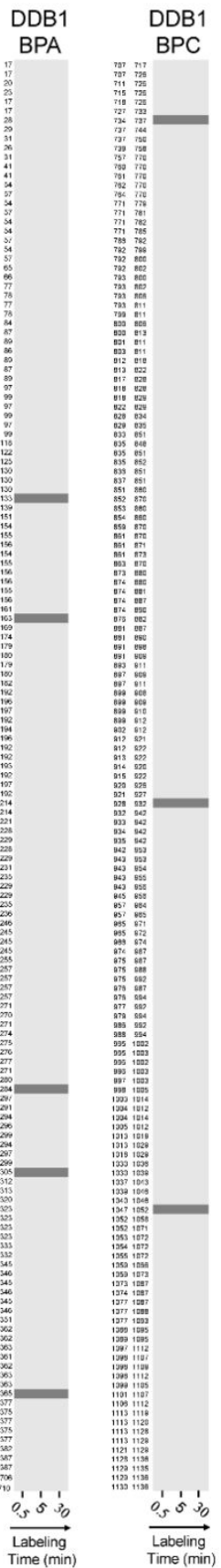

Figure S4. Formation of the ternary complex with CFT-1297 did not result in additional shielding on DDB1 or the portion of CRBN that inserts into the DDB1 domain (A) Sequence coverage for DDB1 $\triangle B P B$ identified in the HDX-MS. The gray box highlights the linker region that connects $\beta$-propeller $A(B P A)$ to $\beta$-propeller $C$ (BPC).

(B) Heat map of DDB1 peptides colored by difference in relative fractional uptake for the ternary complex with CFT-1297. Differences in relative fractional uptake between the binary (CRBNDDB1 $\triangle$ BPB+CFT-1297) and ternary (CRBN-DDB1 $\triangle B P B+C F T-1297+B D 1)$ are illustrated with peptic peptides showing less than 10\% difference in gray, $10-15 \%$ difference in orange, and greater than $15 \%$ difference colored in red. The peptides are broken into the BPA and BPC domains. Missing peptides are colored in dark gray. 
(C) Sequence coverage of CRBN, with peptic peptides that bind DDB1 highlighted in dark gray. (D) Heat map of CRBN peptides that bind the DDB1 $\beta$-propellers in the ternary complex experiment with CFT-1297. Differences in relative fractional uptake identical to (B) using the same coloring scheme. 


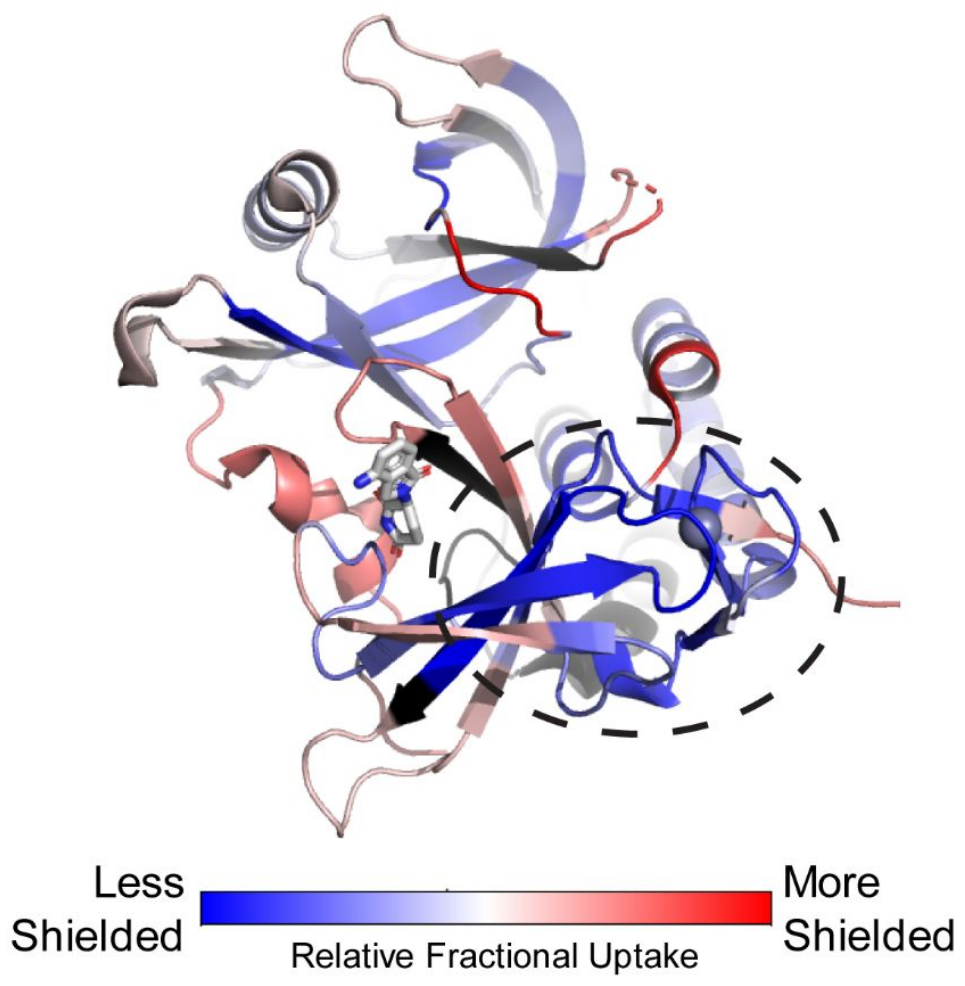

Figure S5. CRBN-DDB1 $\triangle B P B$ alone reveals conformational dynamics of protein Deuterium uptake of CRBN in the absence of compound colored from blue (least uptake) to red (most uptake). Dashed oval highlights the zinc binding region that showed no deuterium uptake. (PDB file 4TZ4 with ligand shown as sticks to orient viewer and define binding site). 

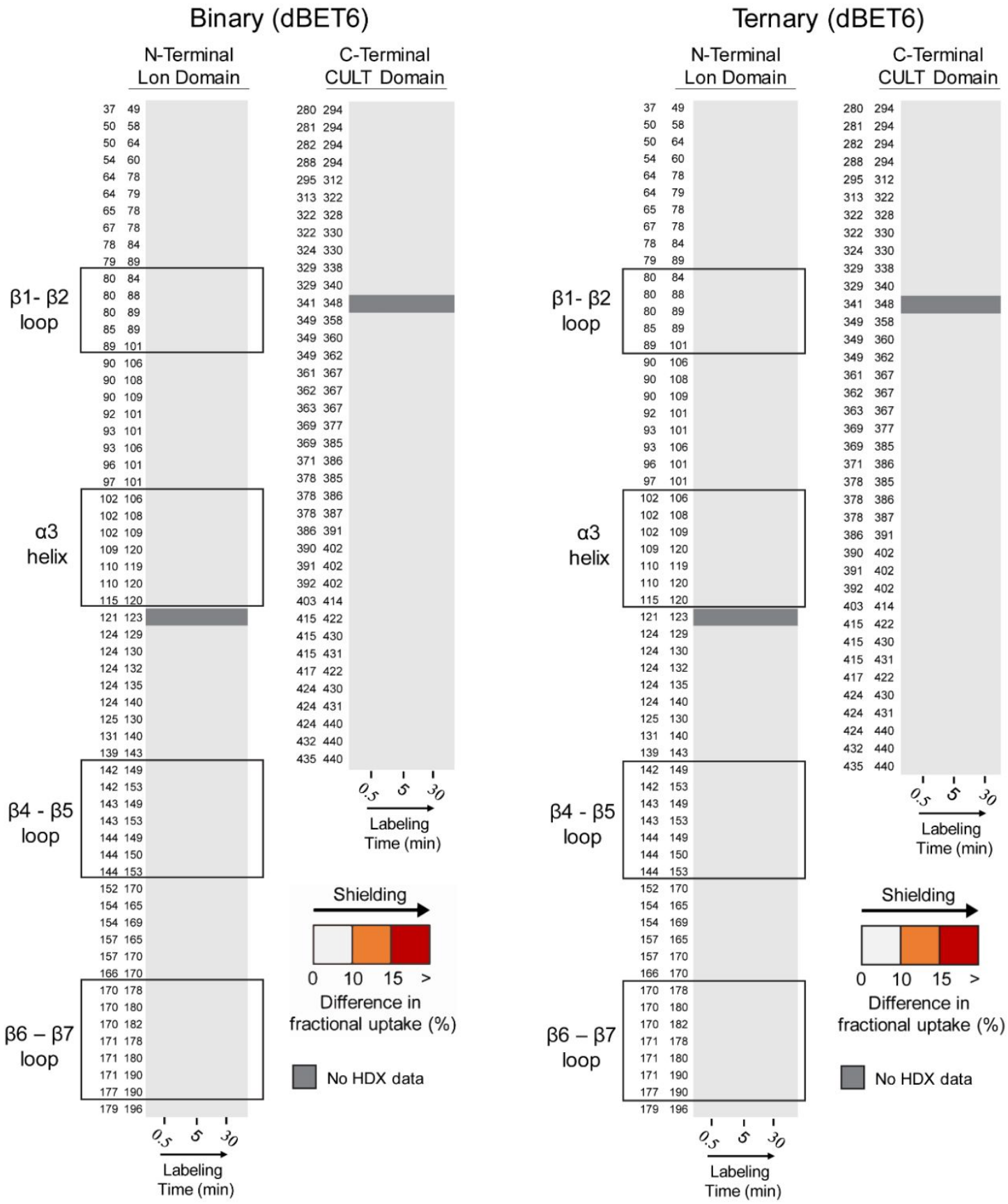

Figure S6. CRBN peptides from the ternary complex with dBET6 show no significant difference in deuterium uptake compared to the binary compound-only experiment Heat map of CRBN peptides colored by difference in relative fractional uptake. The binary experiment (left) shows shielding from the dBET6 compound alone, subtracting the relative fractional uptake between the DMSO control and CRBN-DDB1 $\triangle B P B+d B E T 6$ experiment. The ternary experiment (right) shows shielding from the complex built by dBET6, subtracting the relative fractional uptake between $C R B N-D D B 1 \triangle B P B+d B E T 6$ and $C R B N-$

DDB1 $\triangle \mathrm{BPB}+\mathrm{dBET} 6+\mathrm{BD} 1$ experiment. No peptides showed greater than a $10 \%$ difference in fractional uptake. Peptides derived from loops and helices that showed shielding events in the CFT-1297 experiment are boxed. Missing peptides are colored dark gray. 


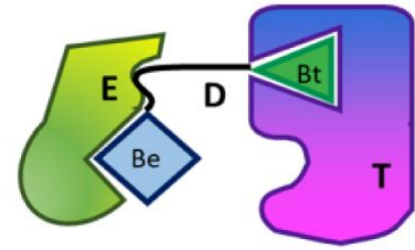

Ternary Complex (EDT)

Computational Workflow

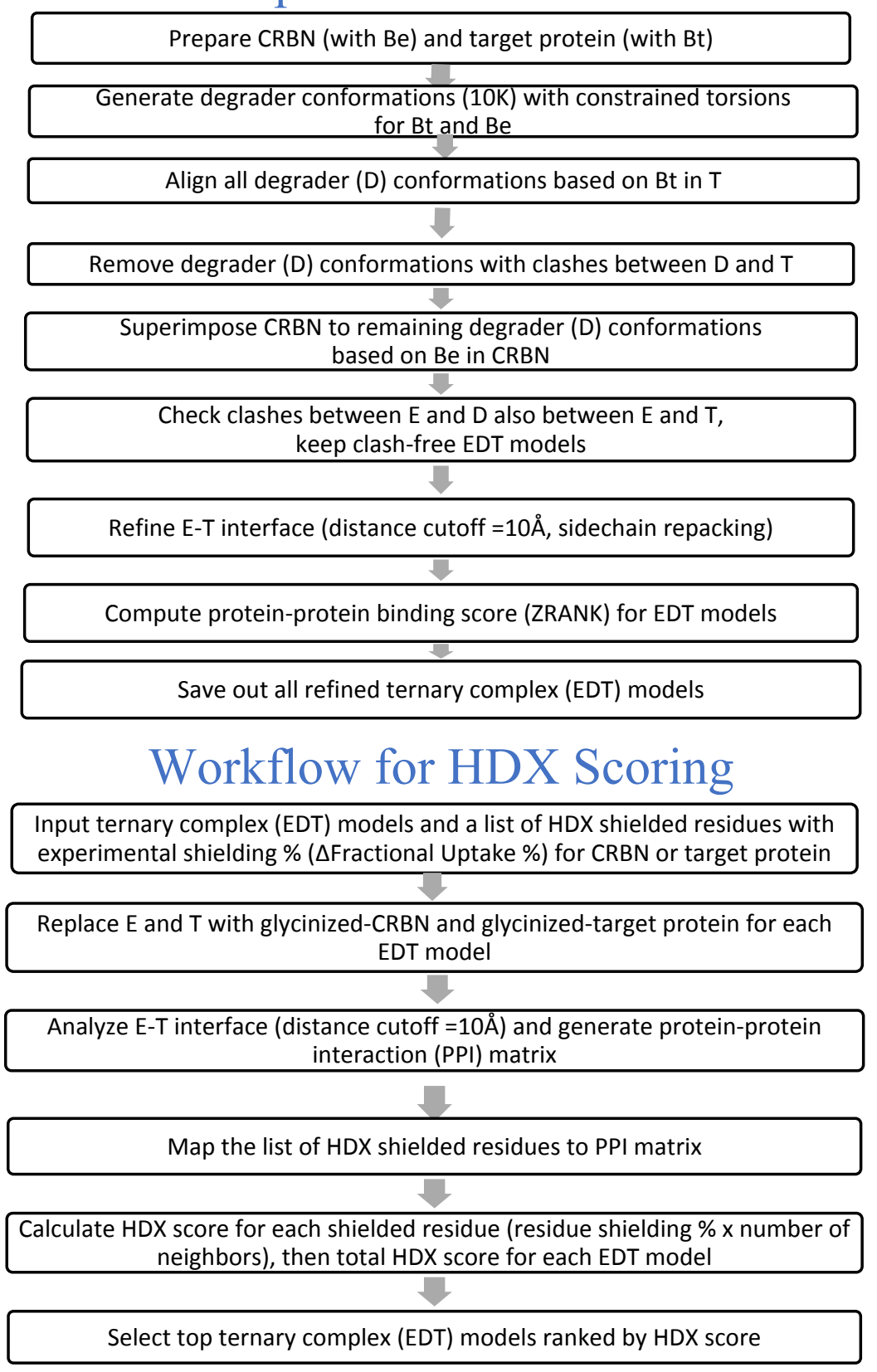

Figure S7. Computational workflow and HDX scoring

Ternary complex (EDT) cartoon with pieces E (E3 ligase), D (degrader), T (target protein), Be (portion binding to ligase), and Bt (portion binding to target). 


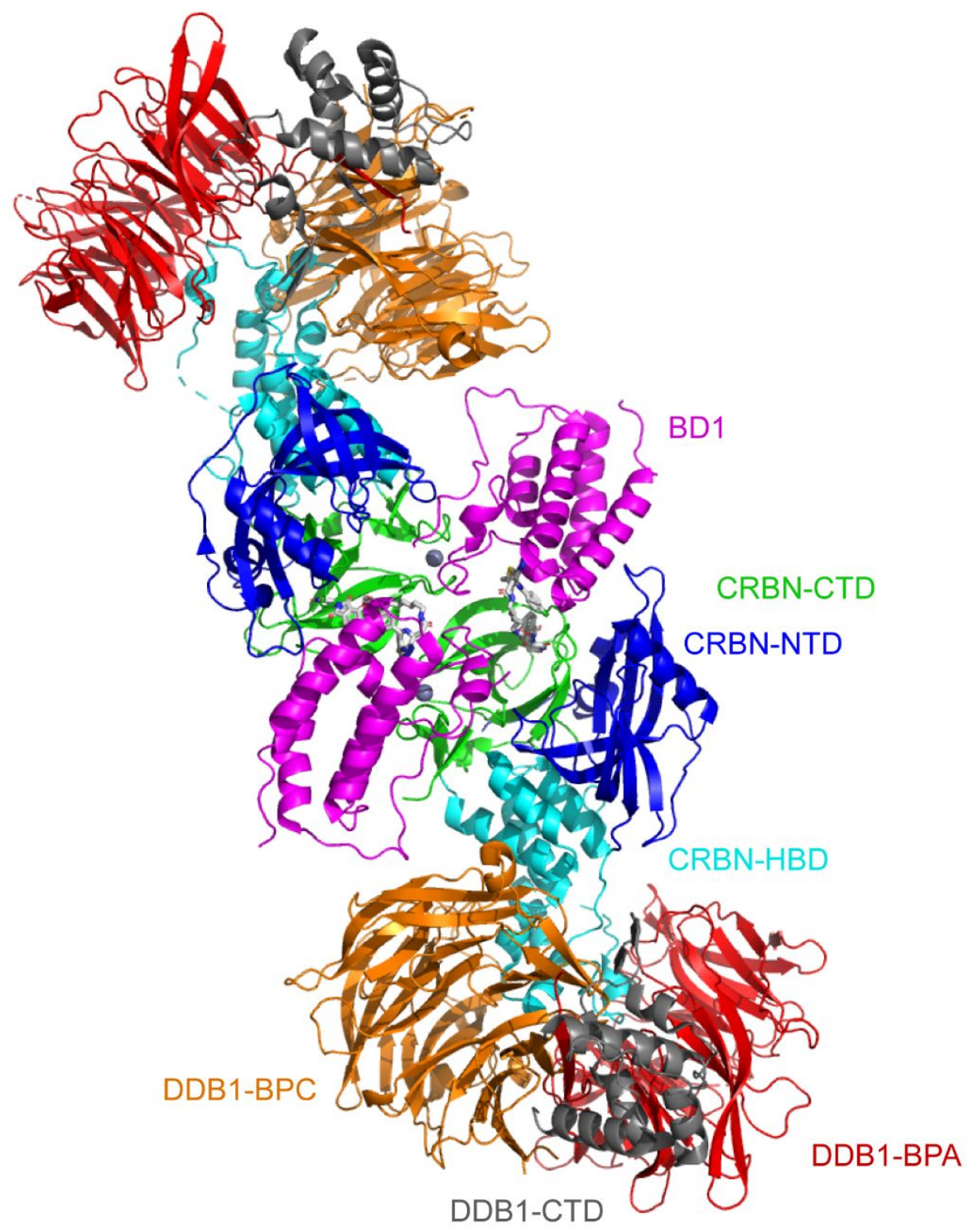

Figure S8: Symmetry mates and crystal contacts for the ternary complex BD1-dBET6-CRBNDDB1 $\triangle B P B$ (PDB: 6BOY)

Cartoon representation of ternary complex with DDB1-BPA (red), DDB1-BPC (orange), DDB1CTD (gray), CRBN NTD (blue), CRBN HBD (cyan), CRBN-CTD (green), and BD1 (magenta). The symmetry mate of this complex is displayed with the crystal contacts of the BD1 domain against the zinc (gray sphere) binding portion of the CRBN-CTD. The symmetry mate has the same color convention as noted above. 


\section{Additional Methods}

\section{BRD4 (BD1) expression and purification}

The BD1 domain of BRD4 (residues 44-168) was subcloned into the pET30a vector with an Nterminal $6 x$ histidine tag and a thrombin cleavage site. Protein was expressed in BL21(DE3) $E$. coli cells after a fresh transformation. Cultures were grown in LB medium with kanamycin (50 $\mu \mathrm{g} / \mathrm{mL}$, ThermoFisher) at $37^{\circ} \mathrm{C}$ until they reached an $\mathrm{OD}_{600}$ of approximately 0.6 . The temperature was reduced to $18{ }^{\circ} \mathrm{C}$ and cells were induced with $100 \mu \mathrm{M}$ isopropyl $\beta-\mathrm{D}-1$ thiogalactopyranoside (IPTG) and allowed to shake at $250 \mathrm{rpm}$ for $18 \mathrm{hrs}$. Cells were harvested by centrifugation at $5500 \mathrm{rcf}$ for $10 \mathrm{~min}$ and cell pellets were stored at $-80^{\circ} \mathrm{C}$. Frozen pellets were thawed and resuspended in lysis buffer containing $50 \mathrm{mM} \mathrm{HEPES} \mathrm{pH} \mathrm{8.0,300} \mathrm{mM} \mathrm{NaCl,}$ $20 \mathrm{mM}$ imidazole, $1 \mathrm{mM} \beta$-mercaptoethanol, $1 \mathrm{mg} / \mathrm{mL}$ lysozyme (Alfa Aesar), $10 \mathrm{mM} \mathrm{MgCl}_{2}$, and a 1:10000 bovine DNase I (Sigma). Cells were lysed by French press and centrifuged at 32,000 rcf for $45 \mathrm{~min}$ to remove cellular debris. The clarified lysate was mixed with Ni-NTA agarose (Qiagen) and agitated by rotation for $1 \mathrm{~h}$. The mixture was added to a BioRad gravity flow column and washed. Protein was eluted with buffer containing $50 \mathrm{mM} \mathrm{HEPES} \mathrm{pH} \mathrm{8.0,300} \mathrm{mM}$ $\mathrm{NaCl}, 250 \mathrm{mM}$ imidazole, and $1 \mathrm{mM} \beta$-mercaptoethanol. Pooled elution fractions with incubated with thrombin and dialyzed overnight at $4{ }^{\circ} \mathrm{C}$ in $10 \mathrm{k}$ molecular weight cutoff tubing (ThermoFisher). The cleaved material was subjected to a reverse nickel purification, concentrated, and loaded onto a Superdex 75 10/300 GL (GE Healthcare) size exclusion column. The column was run at $0.8 \mathrm{~mL} / \mathrm{min}$ at $4{ }^{\circ} \mathrm{C}$ whilst collecting $2 \mathrm{~mL}$ fractions. Fractions were analyzed by SDS-PAGE and the peak was concentrated to $16.3 \mathrm{mg} / \mathrm{mL}$ and stored in sizing buffer containing $25 \mathrm{mM} \mathrm{HEPES} \mathrm{pH} 7.5$ and $200 \mathrm{mM} \mathrm{NaCl}$.

The BRD4 (BD1) protein for assays was purified in an identical manner. Notably, this construct had an N-terminal AVI tag (GLNDIFEAQKIEWHE) that was maintained after the protease cleavage step. Purified Avi tagged BD1 protein was biotinylated using the BirA biotin-protein ligase standard reaction kit (Avidity) according to manufacturer's instructions.

\section{CRBN-DDB1 expression and purification}

The 6xHis-Avi-TEV-tagged human CRBN (40-442) and untagged human DDB1 $\triangle B P B$ were coexpressed in High Five insect cells. The human DDB1 $\triangle B P B$ consists of residues 1-395 followed by a GNGNSG linker that replaces the $\beta$-propeller B and ends with residues 706-1140 as described previously. ${ }^{1,2}$ Cells were resuspended in lysis buffer containing $50 \mathrm{mM}$ Tris $\mathrm{pH} 8.5$, $200 \mathrm{mM} \mathrm{NaCl}, 1 \mathrm{mM} \beta$-mercaptoethanol, 0.1\% TritonX-100, $1 \mathrm{mM}$ PMSF, and 1x complete protease inhibitor EDTA free (Roche) and lysed with a high-pressure homogenizer. Lysate was centrifuged for $60 \mathrm{~min}$ at 18,000 rpm and then loaded onto a TALON fast flow column. The column was extensively washed with buffer containing $50 \mathrm{mM}$ Tris $\mathrm{pH} 8.5,200 \mathrm{mM} \mathrm{NaCl}$, and 1 $\mathrm{mM} \beta$-mercaptoethanol. CRBN-DDB1 $\triangle \mathrm{BPB}$ was eluted with wash buffer plus $500 \mathrm{mM}$ imidazole. Eluted fractions were incubated with TEV protease and dialyzed overnight at $4{ }^{\circ} \mathrm{C}$. Cleaved material was subjected to reverse Ni-affinity using a HisTrap HP $5 \mathrm{~mL}$ column (GE Healthcare) and eluted with buffer containing $50 \mathrm{mM}$ Tris pH 8.5, $200 \mathrm{mM} \mathrm{NaCl}, 1 \mathrm{mM} \beta$ mercaptoethanol, and $20 \mathrm{mM}$ imidazole. The eluted material was loaded onto a $6 \mathrm{~mL}$ Resource $Q$ column (GE Healthcare) and baselined with buffer A consisting of $50 \mathrm{mM}$ Tris pH 8.5, 150 $\mathrm{mM} \mathrm{NaCl}$, and $1 \mathrm{mM}$ TCEP. The complex was eluted with a salt gradient as buffer $\mathrm{B}$ was introduced, which contained $50 \mathrm{mM}$ Tris $\mathrm{pH} 8.5,150 \mathrm{mM} \mathrm{NaCl}, 1 \mathrm{mM}$ TCEP, and $500 \mathrm{mM} \mathrm{NaCl}$. 
The peak corresponding to the CRBN-DDB1 $\triangle \mathrm{BPB}$ complex was then concentrated and loaded onto a HiLoad Superdex 200 16/60 GL size exclusion column with buffer containing $25 \mathrm{mM}$ HEPES pH 7.5, $300 \mathrm{mM} \mathrm{NaCl}$, and $1 \mathrm{mM}$ TCEP. The resulting CRBN-DDB1 $\triangle \mathrm{BPB}$ complex was then concentrated to approximately $10 \mathrm{mg} / \mathrm{mL}$ and flash frozen in aliquots stored at $-80{ }^{\circ} \mathrm{C}$.

The 6xHis-tagged full length CRBN (1-442) and untagged human DDB1 (1-1140) were used for assays. This CRBN-DDB1 FL material was expressed, lysed, and followed the TALON affinity chromatography purification as described above for CRBN-DDB1 $\triangle B P B$. After imidazole elution from the TALON column, the CRBN-DDB1 FL complex was loaded onto a MonoQ 10/100 GL (GE Healthcare) and baselined with buffer A containing $50 \mathrm{mM}$ Tris $\mathrm{pH} 8.5,150 \mathrm{mM} \mathrm{NaCl}$, and $1 \mathrm{mM}$ TCEP. Elution buffer containing $50 \mathrm{mM}$ Tris $\mathrm{pH} 8.5,150 \mathrm{mM} \mathrm{NaCl}, 1 \mathrm{mM}$ TCEP, and $1 \mathrm{M}$ $\mathrm{NaCl}$ was applied over a gradient and fractions containing the CRBN-DDB1 FL complex were pooled. These pooled fractions were desalted using a HiPrep 26/10 desalting column that buffer exchanged the complex into $25 \mathrm{mM}$ HEPES pH 7.5, $300 \mathrm{mM} \mathrm{NaCl}$, and $1 \mathrm{mM}$ TCEP. The protein was flash frozen and stored in aliquots at $-80^{\circ} \mathrm{C}$.

\section{Extended chemical syntheses}

\section{Preparation of (2-amino-5-bromophenyl)(4-chlorophenyl)methanone}<smiles>Nc1ccccc1C(=O)c1ccc(Cl)cc1</smiles><smiles>Nc1ccc(Br)cc1C(=O)c1ccc(Cl)cc1</smiles>

Brought (2-aminophenyl)(4-chlorophenyl)methanone $(4.7 \mathrm{~g}, 20.2 \mathrm{mmol})$ up in DCM (75 mL ) and cooled reaction to $0^{\circ} \mathrm{C}$. Added NBS $(3.59 \mathrm{~g}, 20.2 \mathrm{mmol})$ in one portion and let the reaction gradually warm to r.t. Stirred reaction $\mathrm{O} / \mathrm{N}$ and was complete by $\mathrm{Ic} / \mathrm{ms}$. Diluted the reaction with DCM and water and extracted. Washed organic layer with brine and dried over sodium sulfate. Isolated (2-amino-5-bromophenyl)(4-chlorophenyl)methanone (5.4 g, $17.3 \mathrm{mmol}, 86.1 \%)$ as a yellow crude solid. LCMS (ES+): $\mathrm{m} / \mathrm{z}=310[\mathrm{M}+\mathrm{H}]+$

\section{Preparation of tert-butyl (1-(4-bromo-2-(4-} chlorobenzoyl)phenyl)carbamoyl)cyclopropyl)carbamate<smiles>Nc1ccc(Br)cc1C(=O)c1ccc(Cl)cc1</smiles>

Brought (2-amino-5-bromophenyl)(4-chlorophenyl)methanone (3.78 g, $12.1 \mathrm{mmol}), \mathrm{N}$-ethyl-Nisopropylpropan-2-amine $(3.12 \mathrm{~g}, 24.2 \mathrm{mmol})$ and 1-((tertbutoxycarbonyl)amino)cyclopropanecarboxylic acid $(2.43 \mathrm{~g}, 12.1 \mathrm{mmol})$ up in DMF $(5 \mathrm{~mL})$ and cooled to $0^{\circ} \mathrm{C}$. Added HATU $(4.60 \mathrm{~g}, 12.1 \mathrm{mmol})$ and let gradually warm to r.t. O/N. stirred for 8 
days. Diluted into EA and washed with water $2 x$ followed by $5 \% \mathrm{Aq} \mathrm{LiCl} 2 \mathrm{x}$. Dried over sodium sulfate. concentrated. purified by isco $0-40 \% \mathrm{EA} / \mathrm{hx}$ to give tert-butyl (1-((4-bromo-2-(4chlorobenzoyl)phenyl)carbamoyl)cyclopropyl)carbamate (3.42 g, $6.92 \mathrm{mmol}, 57.2 \%)$ as a solid. LCMS (ES+): $\mathrm{m} / \mathrm{z}=437\left[\mathrm{M}-\mathrm{C}_{4} \mathrm{H}_{8}\right]+$

\section{Preparation of 1-amino-N-(4-bromo-2-(4-chlorobenzoyl)phenyl)cyclopropanecarboxamide}

BocHN<smiles>NC1(C(=O)Nc2ccc(Br)cc2C(=O)c2ccc(Cl)cc2)CC1</smiles><smiles>NC1(C(=O)Nc2ccc(Br)cc2C(=O)c2ccc(Cl)cc2)CC1</smiles>

Brought tert-butyl (1-((4-bromo-2-(4-chlorobenzoyl)phenyl)carbamoyl)cyclopropyl)carbamate $(3.52 \mathrm{~g}, 7.12 \mathrm{mmol})$ up in chloroform $(16 \mathrm{~mL})$ and added $4 \mathrm{M}$ hydrogen chloride $(8.90 \mathrm{~mL}, 35.6$ $\mathrm{mmol}$ ) in dioxane. Stirred at r.t. overnight. Concentrated solution and partitioned between DCM and sat. sodium bicarbonate solution. Washed Aqueous layer $2 x$ with DCM. Combined organics and dried over sodium sulfate before concentrating to solid 1-amino-N-(4-bromo-2-(4chlorobenzoyl)phenyl)cyclopropanecarboxamide $(2.80 \mathrm{~g}, 7.11 \mathrm{mmol}, 100 \%)$ which was offwhite and used crude. LCMS (ES+): $\mathrm{m} / \mathrm{z}=395[\mathrm{M}+\mathrm{H}]+$

Preparation of 7-bromo-5-(4-chlorophenyl)spiro[benzo[e][1,4]diazepine-3,1'-cyclopropan]2(1H)-one<smiles>CCC(C)(C)C(=O)O</smiles>

Brought 1-amino-N-(4-bromo-2-(4-chlorobenzoyl)phenyl)cyclopropanecarboxamide (2.80 g, $7.12 \mathrm{mmol})$ up in EtOH $(71.2 \mathrm{~mL})$ and added acetic acid $(10.6 \mathrm{~mL}, 178 \mathrm{mmol})$ before heating to $80^{\circ} \mathrm{C}$ overnight. Cooled reaction and concentrated to $\sim 1 / 3$ volume. Collected ppt. to give $7-$ bromo-5-(4-chlorophenyl)spiro[benzo[e][1,4]diazepine-3,1'-cyclopropan]-2(1H)-one (1.60 g, 4.25 $\mathrm{mmol}, 59.9 \%$ ) as an off-white solid. LCMS (ES+): $\mathrm{m} / \mathrm{z}=377[\mathrm{M}+\mathrm{H}]+$

\section{Preparation of 7-bromo-5-(4-chlorophenyl)spiro[benzo[e][1,4]diazepine-3,1'-} cyclopropane]-2(1H)-thione 
<smiles>O=C1Nc2ccc(Br)cc2C(c2ccc(Cl)cc2)=NC12CC2</smiles>

Brought 7-bromo-5-(4-chlorophenyl)spiro[benzo[e][1,4]diazepine-3,1'-cyclopropan]-2(1H)-one (1.65 g, $4.39 \mathrm{mmol})$ up in thf (29.2 $\mathrm{mL})$ and added 2,4-bis(4-methoxyphenyl)-1,3,2,4dithiadiphosphetane 2,4-disulfide $(974 \mathrm{mg}, 2.41 \mathrm{mmol})$ and refluxed overnight. Cooled to r.t. and concentrated from toluene $2 x$ to give crude 7-bromo-5-(4chlorophenyl)spiro[benzo[e][1,4]diazepine-3,1'-cyclopropane]-2(1H)-thione $(1.71 \mathrm{~g}, 4.36 \mathrm{mmol}$, $100 \%)$ as a solid. LCMS (ES+): $\mathrm{m} / \mathrm{z}=393[\mathrm{M}+\mathrm{H}]+$

Preparation of 8-bromo-6-(4-chlorophenyl)-1-methylspiro[benzo[f][1,2,4]triazolo[4,3a][1,4]diazepine-4,1'-cyclopropane]<smiles>S=C1Nc2ccc(Br)cc2C(c2ccc(Cl)cc2)=NC12CC2</smiles><smiles>Cc1nnc2n1-c1ccc(Br)cc1C(c1ccc(Cl)cc1)=NC21CC1</smiles>

Brought 7-bromo-5-(4-chlorophenyl)spiro[benzo[e][1,4]diazepine-3,1'-cyclopropane]-2(1H)thione $(1.71 \mathrm{~g}, 4.39 \mathrm{mmol})$ up in THF $(43.8 \mathrm{~mL})$ added hydrazine hydrate $(2.12 \mathrm{~mL}, 43.8 \mathrm{mmol})$ and stirred for $1 \mathrm{~h}$. Concentrated reaction down and redissolved in toluene $(43.8 \mathrm{~mL})$ and added Triethyl orthoacetate $(10 \mathrm{~mL})$. Heated reaction to $100{ }^{\circ} \mathrm{C}$ for $6 \mathrm{~h}$. Saw some product and some uncyclized intermediate. concentrated to dryness and redissolved in only toluene. Heated O/N. Cooled to r.t. and began concentrating. Precipitate formed at approximately $1 / 2$ the solvent volume. Filtered to give 8-bromo-6-(4-chlorophenyl)-1-methylspiro[benzo[f][1,2,4]triazolo[4,3a][1,4]diazepine-4,1'-cyclopropane] $(1.5 \mathrm{~g}, 3.63 \mathrm{mmol}, 82.6 \%)$ as a light yellow solid. LCMS $(E S+): m / z=413[M+H]+$ 
Preparation of 6-(4-chlorophenyl)-1-methyl-8-(1H-pyrazol-4yl)spiro[benzo[f][1,2,4]triazolo[4,3-a][1,4]diazepine-4,1'-cyclopropane]<smiles>Cc1nnc2n1-c1ccc(-c3cn[nH]c3)cc1C(c1ccc(Cl)cc1)=NC1(CC1)c1nnc(C)n1-2</smiles>

8-bromo-6-(4-chlorophenyl)-1-methylspiro[benzo[f][1,2,4]triazolo[4,3-a][1,4]diazepine-4,1'cyclopropane] (0.55 g, $1.32 \mathrm{mmol})$ 1-methyl-4-(4,4,5,5-tetramethyl-1,3,2-dioxaborolan-2-yl)-1Hpyrazole (274 mg, $1.32 \mathrm{mmol}$ )and potassium carbonate $(547 \mathrm{mg}, 3.96 \mathrm{mmol}$ ) were dissolved in dioxane $(5.28 \mathrm{~mL}$ ) and water $(2.64 \mathrm{~mL})$ (Ar was bubbled through solvents for 10 minutes prior). tetrakis $(86.2 \mathrm{mg}, 0.07468 \mathrm{mmol})$ was added and the vial was purged with Ar and sealed. The reaction was stirred at $95^{\circ} \mathrm{C}$ for $2 \mathrm{~h}$, at which time LCMS showed reaction was complete.

Azeotroped reaction onto celite from toluene and purified on isco $0-10 \% \mathrm{MeOH} / \mathrm{DCM}$ to give 6 (4-chlorophenyl)-1-methyl-8-(1H-pyrazol-4-yl)spiro[benzo[f][1,2,4]triazolo[4,3-a][1,4]diazepine4,1'-cyclopropane] (280.0 mg, $0.698 \mathrm{mmol}, 52.9 \%)$ as an off-white solid. LCMS (ES+): $\mathrm{m} / \mathrm{z}=401$ $[\mathrm{M}+\mathrm{H}]+$

\section{Preparation of 6-(4-chlorophenyl)-1-methyl-8-(1-methyl-1H-pyrazol-4-} yl)spiro[benzo[f][1,2,4]triazolo[4,3-a][1,4]diazepine-4,1'-cyclopropane]<smiles>Cc1nnc2n1-c1ccc(-c3cnn(C)c3)cc1C(c1ccc(Cl)cc1)=NC1(CC1)c1nnc(C)n1-2</smiles>

8-bromo-6-(4-chlorophenyl)-1-methylspiro[benzo[f][1,2,4]triazolo[4,3-a][1,4]diazepine-4,1'cyclopropane] (0.06 g, $0.1450 \mathrm{mmol})$ 1-methyl-4-(4,4,5,5-tetramethyl-1,3,2-dioxaborolan-2-yl)$1 \mathrm{H}$-pyrazole $(30.1 \mathrm{mg}, 0.145 \mathrm{mmol})$ and potassium carbonate $(60.1 \mathrm{mg}, 0.435 \mathrm{mmol})$ were dissolved in dioxane $(580 \mu \mathrm{L})$ and water $(290 \mu \mathrm{L})$ (Ar was bubbled through solvents for 10 minutes prior). tetrakis $(86.2 \mathrm{mg}, 0.07468 \mathrm{mmol})$ was added and the vial was purged with $\mathrm{Ar}$ and sealed. The reaction was stirred at $95^{\circ} \mathrm{C}$ for $2 \mathrm{~h}$, at which time LCMS showed reaction was complete. Azeotroped reaction onto celite from toluene and purified on isco $4 \mathrm{~g}$ column DCM $10 \% \mathrm{MeOH} / \mathrm{DCM}$ to give 6-(4-chlorophenyl)-1-methyl-8-(1-methyl-1H-pyrazol-4yl)spiro[benzo[f][1,2,4]triazolo[4,3-a][1,4]diazepine-4,1'-cyclopropane] (35.0 mg, $0.08435 \mathrm{mmol}$, $58.2 \%)$ as a white solid. LCMS (ES+): $\mathrm{m} / \mathrm{z}=415[\mathrm{M}+\mathrm{H}]+$ 
1H NMR (400 MHz, DMSO-d6) $\delta 8.11(\mathrm{~d}, \mathrm{~J}=0.8 \mathrm{~Hz}, 1 \mathrm{H}), 7.90-7.80(\mathrm{~m}, 2 \mathrm{H}), 7.68$ (d, J = 8.5 $\mathrm{Hz}, 1 \mathrm{H}), 7.57-7.48(\mathrm{~m}, 2 \mathrm{H}), 7.47-7.34(\mathrm{~m}, 3 \mathrm{H}), 3.76(\mathrm{~s}, 3 \mathrm{H}), 2.53(\mathrm{~s}, 3 \mathrm{H}), 1.66$ (ddd, J = 10.0, 7.1, $5.1 \mathrm{~Hz}, 1 \mathrm{H}$ ), 1.33 (ddd, J = 9.9, 7.2, $5.2 \mathrm{~Hz}, 1 \mathrm{H}$ ), 0.71 (dddd, J = 21.7, 10.0, 7.2, $5.0 \mathrm{~Hz}$, $2 \mathrm{H})$.

\section{Preparation of 3-(4-bromo-1-oxoisoindolin-2-yl)piperidine-2,6-dione}<smiles>COC(=O)c1cccc(Br)c1CBr</smiles>

A mixture of methyl 3-bromo-2-(bromomethyl)benzoate $(6.0 \mathrm{~g}, 19.4 \mathrm{mmol})$ 3-aminopiperidine2,6-dione. $\mathrm{HCl}(3.8 \mathrm{~g}, 23.2 \mathrm{mmol})$ and DIEA $(12.5 \mathrm{~g}, 97.0 \mathrm{mmol})$ in $\mathrm{CH} 3 \mathrm{CN}(60 \mathrm{~mL})$ was heated to $90^{\circ}$ Covernight. The reaction was filtered, washed with Ether and dried on high vac to afford 3(4-bromo-1-oxoisoindolin-2-yl)piperidine-2,6-dione $(5.0 \mathrm{~g}, 15.4 \mathrm{mmol}, 79.8 \%)$ as a purple solid. LCMS (ES+): m/z $323[\mathrm{M}+\mathrm{H}]+$

Preparation of tert-butyl 4-(2-(2,6-dioxopiperidin-3-yl)-1-oxoisoindolin-4-yl)-3,6dihydropyridine-1(2H)-carboxylate<smiles>O=C1CCC(N2Cc3c(Br)cccc3C2=O)C(=O)N1</smiles><smiles>CC(C)(C)OC(=O)N1CC=C(B2OC(C)(C)C(C)(C)O2)CC1</smiles><smiles>CC(C)(C)OC(=O)OC1(O)CC(c2cccc3c2CN(C2CCC(=O)NC2=O)C3=O)=CCN1C(=O)OC(C)(C)C</smiles>

To a solution of 3-(4-bromo-1-oxoisoindolin-2-yl)piperidine-2,6-dione (1 g, $3.09 \mathrm{mmol})$, tert-butyl 4-(4,4,5,5-tetramethyl-1,3,2-dioxaborolan-2-yl)-5,6-dihydropyridine-1(2H)-carboxylate (1.14 g, $3.70 \mathrm{mmol})$, cesium carbonate $(3.01 \mathrm{~g}, 9.27 \mathrm{mmol})$ and dioxane $(8 \mathrm{~mL})$ and water $(2 \mathrm{~mL})$ in (4:1) , purged nitrogen for $10 \mathrm{~min}$. Then added Pd(OAc)2 (69.3 mg, $309 \mu \mathrm{mol}) \mathrm{n}$-butyl diadamantyl phosphine $(221 \mathrm{mg}, 618 \mu \mathrm{mol})$ and sealed the cap. stirred the reaction at $100^{\circ} \mathrm{C}$ for $1 \mathrm{~h}$. The reaction progress was monitored by TLC.After completion of reaction quenched the reaction with water $(20 \mathrm{~mL})$ and extracted with ethyl acetate $(10 \mathrm{~mL} \times 3)$.Combined the organic layers and dried over anhydrous sodium sulfate, filtered and distilled, washing with pentane (10 $\mathrm{mLx3}$ ) was given to obtain tert-butyl 4-(2-(2,6-dioxopiperidin-3-yl)-1-oxoisoindolin-4-yl)-5,6dihydropyridine-1 $(2 \mathrm{H})$-carboxylate $(500 \mathrm{mg}, 1.17 \mathrm{mmol}, 38.1 \%)$ as off white solid. LC/MS $(E S+): m / z 426.16[M+H]+$ 


\section{Preparation of 3-(1-oxo-4-(piperidin-4-yl)isoindolin-2-yl)piperidine-2,6-dione 2,2,2- trifluoroacetate}
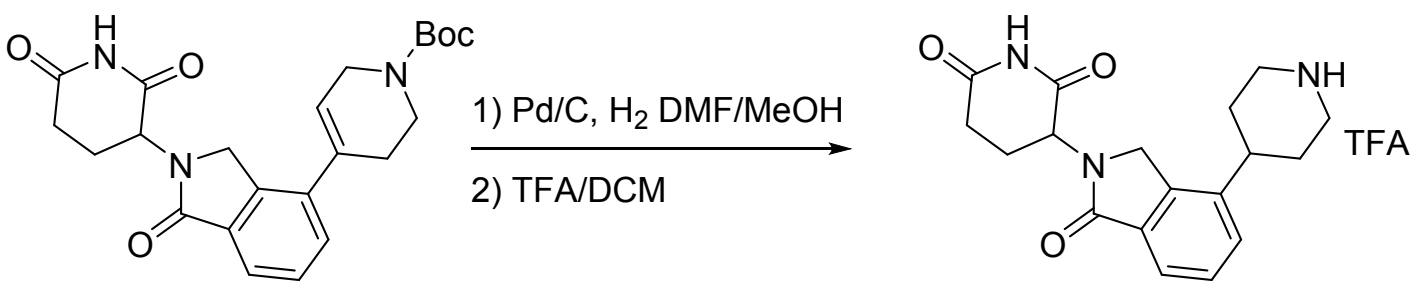

To a solution of tert-butyl 4-(2-(2,6-dioxopiperidin-3-yl)-1-oxoisoindolin-4-yl)-5,6-dihydropyridine$1(2 \mathrm{H})$-carboxylate $(50 \mathrm{mg}, 117 \mu \mathrm{mol})$ in METHANOL $(2.5 \mathrm{~mL})$, DMF $(0.5 \mathrm{~mL})$ added $10 \% \mathrm{Pd} / \mathrm{C}$ $(0 \mu \mathrm{g}, 0 \mu \mathrm{mol})$ and hydrogenated the reaction using balloon pressure for $1 \mathrm{~h}$. The reaction was filtered through a celite bed and concentrated, washing with diethyl ether $(5 \mathrm{~mL} 3$ ) was given to obtain tert-butyl 4-(2-(2,6-dioxopiperidin-3-yl)-1-oxoisoindolin-4-yl)piperidine-1-carboxylate (15.0 $\mathrm{mg}, 35.0 \mu \mathrm{mol}, 30.0 \%$ ) as white solid.LC/MS (ES+): $\mathrm{m} / \mathrm{z} 428.12$ [M+H]+

Tert-butyl 4-(2-(2,6-dioxopiperidin-3-yl)-1-oxoisoindolin-4-yl)piperidine-1-carboxylate (15.0 mg, $35.0 \mu \mathrm{mol})$ was dissolved in DCM $(1.0 \mathrm{~mL})$ and TFA $(0.25 \mathrm{~mL})$ was added. The reaction was stirred for $2 \mathrm{~h}$ and concentrated to give crude 3-(1-oxo-4-(piperidin-4-yl)isoindolin-2yl)piperidine-2,6-dione 2,2,2-trifluoroacetate as a brownish solid which was used as is. LC/MS (ES+): $\mathrm{m} / \mathrm{z} 328[\mathrm{M}+\mathrm{H}]+$

\section{Preparation of 7-(4-(6-(4-chlorophenyl)-1-methylspiro[benzo[f][1,2,4]triazolo[4,3-} a][1,4]diazepine-4,1'-cyclopropan]-8-yl)-1H-pyrazol-1-yl)heptyl methanesulfonate<smiles>Cc1nnc2n1-c1ccc(-c3cnn(CC(C)(C)C)c3)cc1C(c1ccc(Cl)cc1)=NC21CC1</smiles>

To a solution of 6-(4-chlorophenyl)-1-methyl-8-(1H-pyrazol-4-yl)spiro[benzo[f][1,2,4]triazolo[4,3a][1,4]diazepine-4,1'-cyclopropane] $(1.0 \mathrm{~g}, 2.49 \mathrm{mmol})$ in DMF $(10.0 \mathrm{~mL})$, Cesium carbonate $(2.43 \mathrm{~g}, 7.47 \mathrm{mmol})$ was added followed by the addition of 7 -bromoheptan-1-ol $(971 \mathrm{mg}, 4.98$ $\mathrm{mmol}$ ) at $0{ }^{\circ} \mathrm{C}$. The reaction mixture was stirred at $\mathrm{rt}$ for $24 \mathrm{~h}$. The reaction progress was monitored by TLC and LCMS analysis. The reaction mixture was quenched with ice water (15.0 $\mathrm{mL})$ and extracted with ethyl acetate $(30.0 \mathrm{mLx} 3)$. The organic layers were washed with brine, dried over sodium sulfate, filtered and concentrated to afford 7-(4-(6-(4-chlorophenyl)-1methylspiro[benzo[f][1,2,4]triazolo[4,3-a][1,4]diazepine-4,1'-cyclopropan]-8-yl)-1H-pyrazol-1yl)heptan-1-ol (850 mg, $1.65 \mathrm{mmol}, 66.4 \%)$ as brown solid. LCMS (ES+): m/z=515 [M + H]+

To a solution of 7-(4-(6-(4-chlorophenyl)-1-methylspiro[benzo[f][1,2,4]triazolo[4,3a][1,4]diazepine-4,1'-cyclopropan]-8-yl)-1 H-pyrazol-1-yl)heptan-1-ol (200 mg, $388 \mu \mathrm{mol})$ in DCM $(4 \mathrm{~mL})$, Triethylamine $(322 \mu \mathrm{L}, 2.32 \mathrm{mmol})$ was added followed by the addition of Methanesulfonyl chloride $(89.1 \mu \mathrm{L}, 1.16 \mathrm{mmol})$ at $0{ }^{\circ} \mathrm{C}$. The reaction progress was monitored by 
TLC and LCMS analysis. The reaction mixture was diluted with $\mathrm{DCM}(25.0 \mathrm{~mL})$ and washed with waster $(15.0 \mathrm{mLx} 3)$. The organic layers were dried over sodium sulfate, filtered and concentrated to afford 7-(4-(6-(4-chlorophenyl)-1-methylspiro[benzo[f][1,2,4]triazolo[4,3-a][1,4]diazepine-4,1'cyclopropan]-8-yl)-1H-pyrazol-1-yl)heptyl methanesulfonate $(210 \mathrm{mg}, 354 \mu \mathrm{mol}, 91.3 \%)$ as brown solid. LCMS $(E S+): m / z=593[M+H]+$

Preparation of 3-(4-(1-(7-(4-(6-(4-chlorophenyl)-1-methylspiro[benzo[f][1,2,4]triazolo[4,3a][1,4]diazepine-4,1'-cyclopropan]-8-yl)-1 H-pyrazol-1-yl)heptyl)piperidin-4-yl)-1oxoisoindolin-2-yl)piperidine-2,6-dione
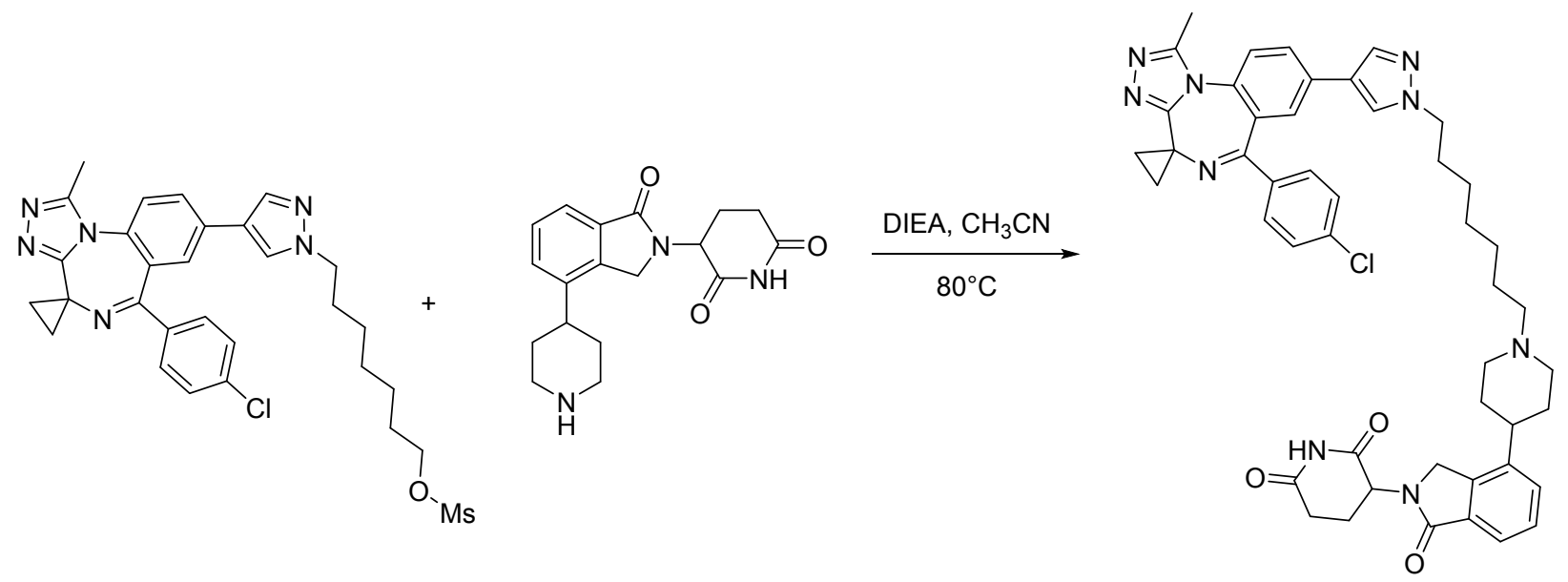

To a solution of 3-(1-oxo-4-(piperidin-4-yl)isoindolin-2-yl)piperidine-2,6-dione (98.8 mg, 302 $\mu \mathrm{mol})$ Acetonitrile $(10 \mathrm{~mL}), \mathrm{N}, \mathrm{N}$-diisopropylethyl amine $(227 \mathrm{mg}, 1.76 \mathrm{mmol})$ was added and stirred for 15 minute at room temperature followed by addition of 7-(4-(6-(4-chlorophenyl)-1methylspiro[benzo[f][1,2,4]triazolo[4,3-a][1,4]diazepine-4,1'-cyclopropan]-8-yl)-1H-pyrazol-1yl)heptyl methanesulfonate $(150 \mathrm{mg}, 252 \mu \mathrm{mol})$ and heated the reaction mixture at $80^{\circ} \mathrm{C}$ for 16 h. After showed TLC completion, the resulting reaction mixture was quenched with ice water and extracted with EA $(2 \times 20 \mathrm{~mL})$ and resulting organic phase was dried over sodium sulfate and concentrated under reduced pressure. The resulting crude material was purified by column chromatography by using $10 \% \mathrm{MeOH}$ in DCM as eluent to give 3-(4-(1-(7-(4-(6-(4chlorophenyl)-1-methylspiro[benzo[f][1,2,4]triazolo[4,3-a][1,4]diazepine-4,1'-cyclopropan]-8-yl)1H-pyrazol-1-yl)heptyl)piperidin-4-yl)-1-oxoisoindolin-2-yl)piperidine-2,6-dione (84.6 mg, 102 $\mu \mathrm{mol}, 40.8 \%)$ as a white solid. LCMS (ES +$): \mathrm{m} / \mathrm{z}=825[\mathrm{M}+\mathrm{H}]+$

1H NMR (400 MHz, DMSO- d6) ס 0.74-0.81 (m, 2H), 1.19-1.30 (m, 10H), 1.35-1.42 (m, 2H), 1.68-1.78 (m, 6H), 1.91-2.09 (m, 4H), $2.59(\mathrm{~s}, 3 \mathrm{H}), 2.58-2.64(\mathrm{~m}, 2 \mathrm{H}), 2.85-2.95(\mathrm{~m}, 2 \mathrm{H}), 3.51-$ $3.61(\mathrm{~m}, 1 \mathrm{H}), 4.09-4.12(\mathrm{~m}, 2 \mathrm{H}), 4.35(\mathrm{~d}, \mathrm{~J}=18.4 \mathrm{~Hz}, 1 \mathrm{H}), 5.05(\mathrm{~d}, \mathrm{~J}=18.2 \mathrm{~Hz}, 1 \mathrm{H}), 5.15(\mathrm{dd}, \mathrm{J}$ $=13.6 \mathrm{~Hz} \& 3.4 \mathrm{~Hz}, 1 \mathrm{H}), 7.45(\mathrm{~d}, \mathrm{~J}=2.0 \mathrm{~Hz}, 1 \mathrm{H}), 7.48-7.50(\mathrm{~m}, 4 \mathrm{H}), 7.56-7.63(\mathrm{~m}, 3 \mathrm{H}), 7.74(\mathrm{~d}$, $\mathrm{J}=8.4 \mathrm{~Hz}, 1 \mathrm{H}), 7.90(\mathrm{~s}, 1 \mathrm{H}), 7.94(\mathrm{dd}, \mathrm{J}=8.4 \mathrm{~Hz} \& 2.0 \mathrm{~Hz}, 1 \mathrm{H}), 8.23(\mathrm{~s}, 1 \mathrm{H}), 11.01(\mathrm{~s}, 1 \mathrm{H})$.

dBET6 was synthesized using previously established methods. ${ }^{3}$ 


\section{References}

(1) Nowak, R. P.; DeAngelo, S. L.; Buckley, D.; He, Z.; Donovan, K. A.; An, J.; Safaee, N.; Jedrychowski, M. P.; Ponthier, C. M.; Ishoey, M.; Zhang, T.; Mancias, J. D.; Gray, N. S.; Bradner, J. E.; Fischer, E. S. Plasticity in Binding Confers Selectivity in Ligand-Induced Protein Degradation. Nat Chem Biol 2018, 14 (7), 706-714.

(2) Petzold, G.; Fischer, E. S.; Thomä, N. H. Structural Basis of Lenalidomide-Induced CK1 1 a Degradation by the CRL4CRBN Ubiquitin Ligase. Nature 2016, 532 (7597), 127-130.

(3) Winter, G. E.; Mayer, A.; Buckley, D. L.; Erb, M. A.; Roderick, J. E.; Vittori, S.; Reyes, J. M.; Iulio, J. di; Souza, A.; Ott, C. J.; Roberts, J. M.; Zeid, R.; Scott, T. G.; Paulk, J.; Lachance, K.; Olson, C. M.; Dastjerdi, S.; Bauer, S.; Lin, C. Y.; Gray, N. S.; Kelliher, M. A.; Churchman, L. S.; Bradner, J. E. BET Bromodomain Proteins Function as Master Transcription Elongation Factors Independent of CDK9 Recruitment. Mol Cell 2017, 67 (1), 5-18.e19. 